\title{
ORBITAL MORPHOLOGY OF TELANGANA REGION: A DIRECT MEASUREMENT STUDY
}

\author{
Nagaraj. S *1, Gayatri.N 2, Anil. R. Sherke ${ }^{3}$.
}

${ }^{* 1}$ Assistant Professor, Department of Anatomy, Kamineni Institute of M edical Sciences, Narketpally, Telangana, India.

${ }^{2}$ Associate Professor, Department of Anatomy, Kamineni Institute of M edical Sciences, Narketpally, Telangana, India.

${ }^{3}$ Professor \& Head, Department of Anatomy, Kamineni Institute of M edical Sciences, Narketpally, Telangana, India.

\section{ABSTRACT}

Background: Orbit is pyramidal cavity in the facial skeleton with its apex at the optical canal. The dimensions of the orbital cavity vary in populations belonging to different geographical areas. The present study was conducted so as to know such differences which will further aid in anthropological and forensic evaluation of skulls.

Materials: The study involved 100 dry skulls collected from Anatomy department of KIM S, Narketpally and also from medical and dental students. Orbital height $(\mathrm{OH})$ and orbital breadth $(\mathrm{OB})$ of both sides were measured using digital vernier calipers. Orbital index (OI) was then calculated with the formula $\mathrm{Ol}=\mathrm{OH} / \mathrm{OB}$ X100

Results: The mean orbital height was $32.42 \mathrm{~mm}$, mean orbital breadth was $36.01 \mathrm{~mm}$ and mean Orbital Index to be 87.39. M aximum orbits measured were of M esoseme type.

Conclusion: The orbital dimensions measured in the present study shows the diversity of orbital morphology in different geographical areas. It also may help in better treatment of orbital pathologies.

KEY WORDS: Orbital morphometry, Dry skull, Orbital Index, M esoseme

Address for Correspondence: Dr. Nagaraj. S, H.No 3-9-487/2, Plot No12, Road No. 2, Bhavani Nagar, M ansoorabad, Hyderabad, India-500068. M obile no: 09502366224. E-Mail: cdrnagraj@ gmail.com

\begin{tabular}{|c|c|c|}
\hline \multicolumn{3}{|c|}{ Access this Article online } \\
\hline \multirow{2}{*}{ 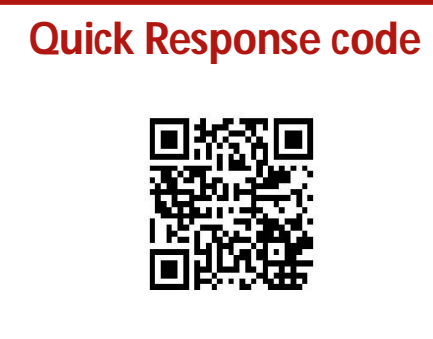 } & \multicolumn{2}{|c|}{$\begin{array}{l}\text { Web site: International Journal of Anatomy and Research } \\
\text { ISSN 2321-4287 } \\
\text { www.ijmhr.org/ijar.htm }\end{array}$} \\
\hline & $\begin{array}{l}\text { Received: } 14 \text { Nov } 2016 \\
\text { Peer Review: } 16 \text { Nov } 2016\end{array}$ & $\begin{array}{l}\text { Accepted: } 20 \text { Dec } 2016 \\
\text { Published (0): } 31 \text { Jan } 2017\end{array}$ \\
\hline DOI: 10.16965/ijar.2016.475 & Revised: None & Published (P): 31 Jan 2017 \\
\hline
\end{tabular}

\section{INTRODUCTION}

Orbits are the most conspicuous feature of the facial skeleton. Orbital morphometry constitutes important part of measuring facial symmetry and also changes in terms of evolutionary development. Conclusions drawn from such studies by anthropologists and anatomists are helpful not only to ophthalmologists but also to maxillofacial and plastic surgeons [1-3].

As pointed out by many previous studies in various parts of the world orbital dimensions vary not only with development, sex and race but also with region [4]. Among various criteria for determining the orbital morphology orbital index is appropriate and easily measurable. Orbital index (OI) is nothing but ratio of orbital height to orbital breadth multiplied by 100 [5].

Based on Orbital index, orbits are categorised as 1. M icroseme ( 0183 or less) 2. M esoseme (OI 83 to 89) 3. Megaseme ( OI 89 and above) [6].

M ean orbital index of a particular population will 
be different from other populations and hence may also differ from others in the above said categories. So the present study was carried out to estimate the orbital index of Telangana region and categorise it to one of the above types.

\section{MATERIALS AND METHODS}

Materials: A total of 100 adult skulls collected from Telangana region were included in the study. The skulls were procured from Anatomy dept, KIMS, Narketpally as well as from M edical and Dental students. The bones having pathological lesions and fractures were excluded.

M ethod: M orphometry of orbit of both right and left side were measured with the help of digital slide callipers. All the measurements were recorded in millimeter.

Orbital Height $(\mathrm{OH})$ defined to be the maximum distance between the superior and inferior margins of the orbital cavity was measured.

Orbital Breadth (OB) defined to be the distance between the midpoint of medial and lateral margins was measured.

Fig. 1: M easurement of Orbital height.

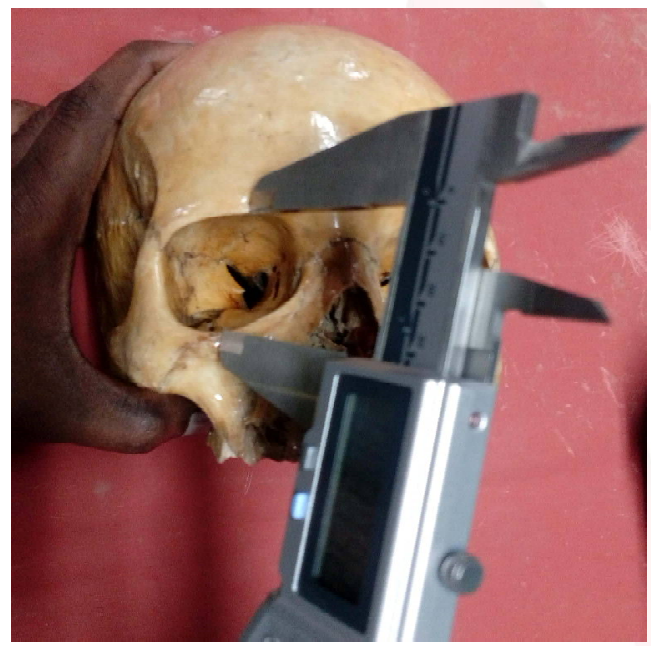

Fig. 2: Measurement of Orbital breadth.

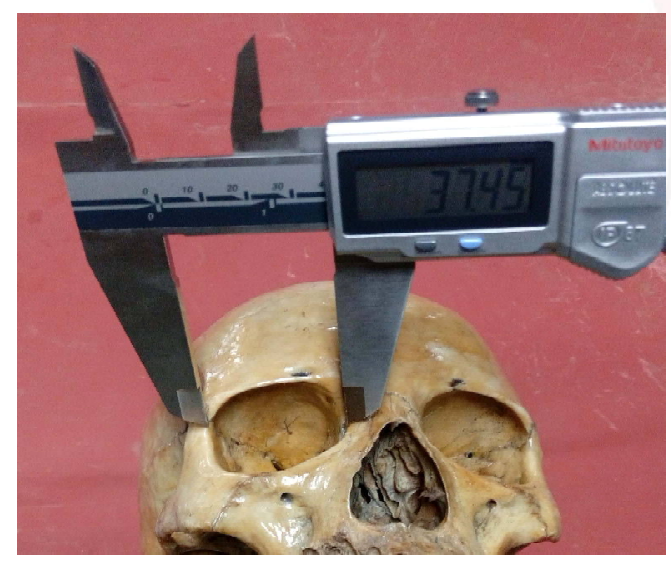

Orbital Index was then calculated using these two parameters by the formula

Orbital Index (OI) = Orbital Height $/$ Orbital Breadth X 100

The results were tabulated and mean and standard deviation calculated. A comparison of the mean values between sides was performed using the independent ' $t$ '-test, $p$-value $\varangle .05$ was considered statistically significant.

\section{RESULTS}

The Range of Orbital Height varied from 29.44 to 35.37 on the right side and from $28.96 \mathrm{~mm}$ to $36.72 \mathrm{~mm}$ on left side respectively. The range of Orbital Breadth varied from $34.22 \mathrm{~mm}$ to 39.62 on right side and from $32.84 \mathrm{~mm}$ to $40.76 \mathrm{~mm}$ on left side respectively.

The mean and the standard deviation values of various parameters on each side is shown in the following table.

Table 1: M orphometry of Orbit.

\begin{tabular}{|c|c|c|c|}
\hline Parameters & $\begin{array}{c}\text { Orbital Height } \\
\text { Mean } \pm S D\end{array}$ & $\begin{array}{c}\text { Orbital Breadth } \\
\text { Mean } \pm \text { SD }\end{array}$ & $\begin{array}{c}\text { Orbital Index } \\
\text { Mean }\end{array}$ \\
\hline Right side & $32.02 \pm 1.82 \mathrm{~mm}$ & $37.01+1.50 \mathrm{~mm}$ & $86.52 \mathrm{~mm}$ \\
\hline Left side & $32.83 \pm 2.17 \mathrm{~mm}$ & $35.02+1.89 \mathrm{~mm}$ & $88.26 \mathrm{~mm}$ \\
\hline
\end{tabular}

While orbital breadth of the right and left sides showed no significant difference, the orbital height and orbital index of the two sides showed $p$ value $\varangle 0.05$ and hence statistically significant.

Considering all the orbits that were measured the mean orbital height was $32.42 \mathrm{~mm}$, mean orbital breadth was $36.01 \mathrm{~mm}$ and mean Orbital Index to be 87.39 .

Table 2: Categories of orbit.

\begin{tabular}{|c|c|c|}
\hline Category & Right & Left \\
\hline Microseme & $13 \%$ & $12 \%$ \\
\hline Mesoseme & $64 \%$ & $54 \%$ \\
\hline Megaseme & $23 \%$ & $34 \%$ \\
\hline
\end{tabular}

It is observed that the majority of the orbits belonged to M esoseme category whether right side $(64 \%)$ or left side $(54 \%)$.

\section{DISCUSSION}

Orbital dimensions of a particular person depend predominantly on the genetic influences. When the Orbital morphology of a population in a geographical area is considered, factors like climate and food habits play a role as well. Hence 
the Orbital Index of populations in different geographic areas varies.

Depending on the Orbital Index the multiple researchers have classified different races to be belonging to one of Microseme, M esoseme and M egaseme category [7].

The orbit of yellow race was found to be of M egaseme variety meaning the orbital height to be more than the orbital breadth. The orbit of white races belonged to M esoseme category while the black races belonged to Microseme category [8].

In the present study the mean orbital height was $32.42 \mathrm{~mm}$. The study conducted on north Indian population by Jaswinder singh et al [9] it measured to be $32.05 \mathrm{~mm}$ and while study done by Gosavi et al [10] on skulls of Maharashtra measured it to be $32.31 \mathrm{~mm}$.

The mean orbital breadth in the present study was $36.01 \mathrm{~mm}$. Jaswinder Singh et al found it to be $39.25 \mathrm{~mm}$ in north Indian population and Gosavi et al found it to be $39.46 \mathrm{~mm}$.

The present study the showed mean Orbital Index to be $87.39 \mathrm{~mm}$ and thus falls into M esoseme category. So the orbital index calculated in the present study is consistent with the study of Howale et al [11] one on Maharashtra population. But it differs from studies done by Ebeye et al [12] on Urhobo male and female population in which orbital index was 78.15 and 78.57respectively, Fathy A Fetouh et al [13] done on Egyptian male where the orbital index was 82.27 and Jaswinder Kaur et al done on North Indian population where orbital index was 81.65 (M icroseme). Also, it differs from the study by Ukoha et al [14] done on Nigerian population where orbital index was 89.21 (M egaseme).

Table 3: showing Orbital index of various populations studied by various authors.

\begin{tabular}{|c|l|c|c|c|}
\hline SI.no & \multicolumn{1}{|c|}{ Authorities } & $\begin{array}{c}\text { No.0f skulls } \\
\text { observed }\end{array}$ & Race/ Region & $\begin{array}{c}\text { Mean orbital } \\
\text { Index }\end{array}$ \\
\hline 1 & Ukoha et a 2011[14] & 70 & Nigerian & 89.21 \\
\hline 2 & Ebeye et al2013 [12] & 236 & Urhobo (male) & 78.15 \\
\hline 3 & Ebeye et al 2013 [12] & 152 & Urhobo (female) & 78.57 \\
\hline 4 & Fathy A Fetouh et al [13] & 30 & Egypt (male) & 82.27 \\
\hline 5 & aswinder Kaur et al2012 [9] & 30 & North India & 81.65 \\
\hline 6 & Gosavi et al 2014[10] & 64 & Maharashtra & 81.88 \\
\hline 7 & Deepak Howale et al2012 [11] & 75 & Maharashtra & 86.4 \\
\hline 8 & Present study & 100 & Telangana & 87.39 \\
\hline
\end{tabular}

Int J Anat Res 2017, 5(1):3354-57. ISSN 2321-4287
The difference observed between the right and left side could be attributed to the differential growth of the two sides of the brain. This needs further investigation since there were no such observations in the past.

\section{CONCLUSION}

The orbital measurements are helpful not only for surgical accuracy but also for preparation of ocular prosthesis. The present study showed the mean orbital index of Telangana region to be $87.39 \mathrm{~mm}$ and of M esoseme variety. More such morphometric studies in Telangana region about should be conducted even by employing radiological methods for better diagnosis and treatment as well as racial characterisation.

\section{ACKNOWLEDGEM ENTS}

I would like to acknowledge the support I got from my colleagues Department of Anatomy, KIMS, Narketpally.

\section{Conflicts of Interests: None}

\section{REFERENCES}

[1]. Novit, M. Facial, upper facial and orbital index in Batak, Klaten and Flores students of Jember University. Dent. J. (Maj.Ked.Gigi). 2006; 39(3):116-119.

[2]. Ghosh A, Manjiri C, Mahaptra S. The craniofacial anthropometric measurements in a population of normal newborns of Kolkata. Nepal journal of medical sciences. 2013;2(2):12-9.

[3]. Munguti J, Mandela P, Butt F. Referencing orbital measuresfor surgical and cosmetic procedures. Ant J of Africa.2012;1(1): 40-45.

[4]. Evereklioglu, C., Doganay, S., Gunduz, A, Tercan, M.,Balat, A. and Cumurcu, T. Craniofacial anthropometry in a Turkish population. Cleft Palate Craniofacial J. 2002;39(2): 208-218.

[5]. Datta A.K: Essentials of human anatomy (Head and Neck); Edit 5; 2009; pp 224; Current books international, Kolkata.

[6]. Patniak, V.V.G., Bala Sanju and Singla Rajan, K. Anatomy of the bony orbits- some applied aspects. J.Anatomical Soc. Ind. 2001;50(1): 59-67.

[7]. "Mesoseme" Webster dictionary. 1913; Retrieved from http://www.webster-dictionary.org/definition/ Mesoseme.

[8]. Igbigbi PS, Ebite LE. Orbital Index of Adult M alawians. Anil Aggrawal's Internet Journal of Forensic Medicine and Toxicology. 2010;11(1).

[9]. Kaur J, Yadav S, Sing Z. Orbital dimentions - A direct measurement study using dry skulls. J. Acad.Indus. Res. 2012;1(6):293-5. 
[10]. Gosavi SN, Jadhav, SD, Zambre, BR. A study of orbital morphometry in Indian dry skulls. Asian journal of Biomedical and Pharmaceutical Sciences, 2014;4(29): 23-25.

[11]. Deepak S. Howale, Jain L. K, Kanaklata lyer, et al. Orbital and Nasal indices of Maharastra region: A direct measurement study using dry skulls. International Journal of Current Reasearch 2012;4(8 ):158-161.

[12]. Ebeye O.A, Otikpo O. Orbital index in Urhobos of Nigeria. IOSR Journal of Dental and Medical Sciences 2013;8(2):51-53.
[13]. Fathy A Fetouh, Dalia Mandour Morphometric analysis of the orbit in adult Egyptian skulls and its surgical relevance. Eur. J. Anat. 2014;18(4):303315.

[14]. Ukoha U., Egwu OA., Okafor IJ., et al. Orbital dimensions of adult male nigerians: a direct measurement study using dry skulls. Int J Biol Med Res.2011;2(3):688-690.

\section{How to cite this article:}

Nagaraj. S, Gayatri.N, Anil. R. Sherke. ORBITAL MORPHOLOGY

OF TELANGANA REGION: A DIRECT M EASUREM ENT STUDY. Int J Anat Res 2017;5(1):3354-3357. DOI: 10.16965/ijar.2016.475 